Edu Consilium: Jurnal BK Pendidikan Islam Vol. 3, No. 1, 2022, hlm. 101-114

DOI: $10.19105 /$ ec.v1i1.1808

ISSN 2503-3417 (online)

ISSN 2548-4311 (cetak)

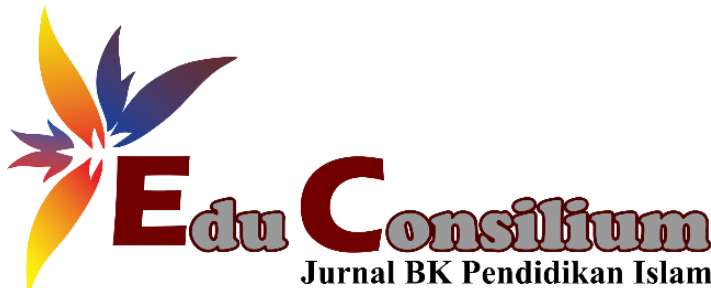

\title{
PEMBERDAYAAN PENYANDANG DISABILITAS BERBASIS KERAJINAN TANGAN
}

\author{
${ }^{1}$ Rina Puspita Sari \\ ${ }^{\mathbf{1}}$ Bimbingan dan Konseling Pendidikan Islam, Universitas Islam Negeri Sunan Kalijaga Yogyakarta \\ rinapuspitasari@gmail.com
}

\begin{tabular}{ll}
\hline Keywords: & Abstract \\
Handcrafting, & This study aims to further explore the empowerment of people with disabilities which is \\
Difabled & carried out personally by Mr. Sulaiman who is also a physically disabled person. The \\
& type of research that will be used is qualitative research, interview, observation, and \\
& documentation methods are used to obtain valid data. The data in this study were \\
& obtained through interviews with Mr. Sulaiman as the owner and pioneer of small and \\
& medium businesses located on Jl. Kaliurang No. Km. 13.5, Besi, Sukoharjo, Kec. \\
& Ngaglik, Sleman Regency, Yogyakarta Special Region. The researcher also uses \\
& secondary data that comes from the documentation data contained in the place of \\
& production of the business which is located next to Mr. Sulaiman's house. The data \\
& analysis technique uses the triangulation method, which is to explore the truth of certain \\
& information through various methods and sources of data acquisition. The results \\
& showed that the empowerment carried out by Mr. Sulaiman for the disabled community \\
& was carried out personally. By starting a business and employing people with disabilities \\
& who have received services from rehabilitation centers. Mr. Sulaiman's employees are \\
also from outside the region such as Pati, Central Java, East Java etc. It also proves that \\
people with disabilities also have a high morale. However, the lack of employment \\
opportunities for people with disabilities is an obstacle even though they have received \\
services from the local rehabilitation center
\end{tabular}

\begin{tabular}{ll}
\hline Kata Kunci: & Pentrak \\
\hline Kerajinan Tangan, & Penyandang disabilitas ini bertujuan untuk mengeksplor lebih jauh tentang pemberdayaan difabel \\
& yang di lakukan secara pribadi oleh bapak sulaiman yang juga sebagai penyandang \\
& disabilitas tuna daksa. Jenis penelitian yang digunakan adalah jenis penelitian kualitatif, \\
& dengan metode wawancara langsung dengan bapak sulaiman agar mendapatkan \\
& informasi dan data yang sebenar-benarnya, observasi dilakukan agar peneliti dapat \\
& menemukan data yang sistematis dan faktual, dan dokumentasi digunakan untuk \\
& memperoleh data yang valid. Data dalam penelitian ini di dapatkan melalui wawancara \\
& kepada Bapak Sulaiman sebagai pemilik dan perintis usaha kecil menengah yang berada \\
& di Jl. Kaliurang No.Km. 13,5, Besi, Sukoharjo, Kec. Ngaglik, Kabupaten Sleman, \\
& Daerah Istimewa Yogyakarta. Peneliti juga menggunakan data sekunder yang berasal \\
& dari data dokumentasi yang terdapat pada tempat produksi usaha tersebut yang terletak \\
& di samping rumah Bapak Sulaiman. Teknik analisis data menggunakan metode \\
& triangulasi, yaitu menggali kebenaran informasi tertentu melalui berbagai metode dan \\
& sumber perolehan data. Hasil penelitian menunjukkan bahwa, pemberdayaan yang di \\
lakukan oleh Bapak Sulaiman terhadap masyarakat disabilitas dilakukan secara pribadi. & Dengan merintis usaha dan mempekerjakan kaum difabel yang sudah mendapatkan \\
pelayanan dari pusat rehabilitasi. Karyawan Bapak Sulaiman juga dari luar daerah \\
\hline
\end{tabular}


seperti pati, jawa tengah, jawa timur dll. Hal itu juga membuktikan bahwa penyandang disabilitas juga memiliki semangat kerja yang tinggi, Akan tetapi minimnya lapangan pekerjaan bagi kaum difabel menjadi kendala meskipun mereka sudah mendapatkan pelayanan dari pusat rehabilitasi setempat.

\section{PENDAHULUAN}

Hand Crafting adalah kerajinan tangan yang di lakukan dengan tangan tanpa membutuhkan alat bantuan serta membutuhkan keterampilan khusus. Biasanya hal itu di lakukan oleh masyarakat yang mempunyai komunitas pengrajian seperti penelitian yang di lakukan oleh Tri Wulandari tentang Pelatihan Kerajinan Tangan Upaya memanfaatkan Peluang Bisnis di Era Pandemi, hal itu menjelaskan baha kerajinan tangan dilakukan karena masyarakat atau kelompok menemukan peluang untuk berbisnis dalam keadaan di rumah saja. Akan tetapi, Hand crafting yang di lakukan oleh bapak sulaiman di lakukan untuk memberdayakan teman-teman yang mengalami disabilitas agar dapat melakukan aktivitas sehari-hari serta menghidupi keluarganya. Hal itu menarik perhatian peniliti untuk meneliti lebih lanjut bagaimana kerajinan tangan yang dilakukan oleh bapak sulaiman sehingga sampai lebih dari sepuluh tahun.

Manusia yang mempunyai keterbatasan fisik atau mental terkadang mengalami masalah kepercayaan diri dalam melakukan semua kegiatan dan rutinitas sehari-hari. Akan tetapi, mereka juga bagian dari Warga Negara Indonesia yang mempunyai hak, dan kewajiban yang sama dengan warga Negara yang lainnya. Agar kelompok disabilitas mempunyai kemampuan dalam menjalani kegiatan sehari-hari maka mereka perlu mendapatkan perhatian yang khusus, terutama perlu perhatian dibidang keterampilan dan pendidikan. Pendidikan dan keterampilan sangat dibutuhkan untuk kepentingan dan kebutuhan sehari-hari mereka, bahkan untuk melanjutkan kehidupannya dimasa yang akan datang, karena mereka para disabilitas tidak akan selamanya bergantung pada keluarganya. Mereka secara sadar atau tidak akan mengalami perubahan hidupnya.

Pada abad ke dua puluh, hampir disemua masyarakat barat disabilitas telah dihubungkan dengan kekurangan pikiran dan tubuh, yaitu meliputi orang pincang, duduk dikursi roda yang menjadi korban keadaan seperti kebutaan, kekurangan pendengaran, sakit jiwa dan gangguan jiwa. Orang-orang yang memiliki kekurangan biasanya tergantung kepada keluarga, teman dan pelayanan social yang kadang berlebihan ditempatkan sebuah lembaga (Kusuma, dkk.2016). 
Sebagian besar dari penyandang cacat tersebut adalah mereka yang dikategorikan anak. Anak-anak butuh perhatian khusus terlebih lagi keadaan social mereka masih sangat rentan mendapatkan deskriminasi dari lingkungan mereka yang tergolong normal. Keluargalah yang berperan penting dalam perkembangan social anak agar menjadi pribadi yang baik di masa depannya. Setiap anak juga memiliki Hak Asasi Manusia, termasuk didalamnya anak berkebutuhan khusus. Mereka juga diakui oleh masyarakat Bangsa-bangsa didunia dan merupakan landasan bagi kemerdekaan, keadilan dan perdamaian diseluruh dunia. Diakui dalam masa pertumbuhan fisik dan mental, anak membutuhkan perawatan, perlindungan yang khusus, serta perlindungan hukum baik sebelum maupun sesudah lahir.

Pelatihan keterampilan untuk para disabilitas yang disediakan oleh lembaga-lembaga agar mereka mampu mengasah skill dan keterampilan mereka, yang nantinya menjadi bekal dan dapat membantu meringankan dan memenuhi kebutuhan mereka sehari-hari. Hal itu berguna untuk mendapatkan pekerjaan atau menjadi sumber penghasilan bagi mereka.

Pekerjaan merupakan bagian penting bagi kehidupan manusia, karena dapat mencukupi kebutuhan sehari-hari, selain itu dapat mengenal lebih banyak orang dan mempunyai banyak relasi. Hal itu juga berlaku bagi anak-anak berkebutuhan khusus. Ia juga perlu mendapatkan pekerjaan yang sesuai dengan kemampuannya agar tidak terjadi hambatan dalam menjalani pekerjaan. Terjadi tekanan dalam pekerjaan dapat menjadikan seseorang terkena gangguan kesehatan karena merasa tidak nyaman dengan aktivitas, lingkungan serta design organisasi kerja yang tidak memadai.

Lingkungan pekerjaan yang stabil menjadi penunjang seseorang untuk tetap produktif dan bekerja lebih giat lagi. Hal itu dikarenakan suasana pekerjaan dan teman-teman yang sepadan dapat membantu mengurangi lelahnya otak setelah bekerja seharian. Hal itu juga berlaku bagi Anak Berkebutuhan Khusus, ia harus berada dalam lingkungan pekerjaan yang dapat menerima dirinya serta tidak menjadikan keterbatasannya sebagai pembeda.

Selain itu, peran pemerintah daerah sangat sentral dilihat dari sisi aksesibilitas fisik maupun non fisik penyandang cacat. Kenyataannya para penyandang disabilitas selama ini belum mendapat kesempatan yang setara dengan masyarakat pada umumnya. Bahkan sebagian orang masih meragukan kemampuan para difabel dalam melakukan aktivitas seharihari. hal itu ditunjukkan ketika para difabel hendak melanjutkan pendidikan di sekolah umum seringkali mendapatkan tanggapan negatif karena adanya gangguan pada fisik sehingga dianggap dapat menghambat aktivitas-aktivitas sosial selama di sekolah, oleh karena itu 
pemerintah membangun sekolah khusus yaitu Sekolah Luar Biasa untuk siswa-siswa yang difabel.

Berdasarkan data Susenas pada 2018, ada 14,2 persen penduduk Indonesia yang menyandang disabilitas atau 30,38 juta jiwa. Untuk pemberdayaan anak-anak yang difabel banyak lembaga yang menjadi pusat rehabilitasi untuk anak-anak, remaja serta lansia yang menyandang kebutuhan fisik. Latihan kerja atau keterampilan ini dibimbing oleh guru - guru khusus yang mempunyai keahlian dibidangnya, dimana bertugas untuk memberi semangat dan pendidikan kepada anak - anak difabel.

Salah satu jenis pekerjaan yang menjadi minat anak difabel adalah hand crafting. Hand crafting adalah hobi atau pekerjaan yang membutuhkan kemampuan dan pengetahuan tertentu untuk menciptakan karya secara terampil. Orang yang menggeluti bidang ini disebut perajin atau pengrajin, tetapi pada zaman sekarang banyak juga disebut sebagai artisan. Orang-orang difabel juga mempunyai kemampuan dalam membuat kerajinan tangan yang hasilnya juga tidak kalah bagus. Meskipun dengan keterbatasan fisik jika di arahkan dengan baik maka hasilnya pun akan sama.

Hand Craft atau kriya merupakan sebuah keterampilan tangan atau kerajinan yang membutuhkan ketelitian untuk setiap detail karyanya. Yang di hasilkan dari kriya adalah produk seni pakai yang bernilai dan bermanfaat. Contoh sederhana dari hasil kriya di indonesia adalah relief atau ukir, batik, sulam, keramik, grafis, cinderamata, anyaman, patung, furniture, hiasan dinding tenun, dll.

Seperti hal nya yang terjadi pada UKM difabel yang di dirikan oleh bapak Sulaiman yang merupakan seorang difabel daksa yang mengalami integritas kehidupan yang tidak mudah sejak ia memutuskan merantau ke provinsi Daerah Istimewa Yogyakarta. Ia mengolah kulit ikan pari menjadi produk jadi, hal itu mempunyai tantangan sendiri karena kulit ikan pari mudah sobek dan jika mengeras maka akan sulit untuk membentuk. Akan tetapi, keunggulan ikan pari ini terdapat butiran-butiran di kulit yang tampak seperti bebatuan mutiara.

Selain ikan pari, bapak sulaiman juga menggunakan kulit sapi untuk digunakan sebagai bahan dalam pembuatan tas atau dompet, sedangkan untuk bahan luarnya ia menggunakan kulit ikan pari. Kulit ikan pari yang di anggap limbah oleh sebagian orang ternyata menjadi ide yang kreatif bagi bapak sulaiman dan rekannya. Jarang sekali di indonesia aksesoris yang terbuat dari ikan pari, umumnya terbuat dari kulit sapi, buaya dan 
ular. Oleh karena itu aksesoris yang terbuat dari ikan pari sangatlah unik dan menarik, terlebih lagi terdapat butiran-butiran mutiara di kulit ikan pari, hal itu membuat semakin menariknya nilai ke eksotisan aksesoris tersebut.

Teknik pengerjaan aksesoris kulit ikan pari berbeda dengan pengerjaan kulit ikan sapi, teksturnya yang keras dan tidak mudah di bentuk membuat pengrajin kurang banyak meminatinya untuk di olah. Akan tetapi, di balik kesukaran dalam mengolah kulit ikan pari juga mempunyai kualitas ketahanan kulit yang sangat tinggi dan tidak mudah tergores. Kekuatan kulit ikan sapi hampir sekitar dua setengah kali kekuatan kulit ikan sapi, sayangnya sejauh ini belum ada tekhnologi yang memadai untuk mengolah kulit ikan pari.

Seperti yang terjadi dengan bapak sulaiman dan rekannya, ia masih sedikit menggunakan alat tekhnologi dalam pembuatan kerajinan kulit ikan pari, mereka masih manual dalam pengerjaan kulit ikan pari. Seperti memotong kulit, mengkilap, menjahit dan lain-lain. Penelitian ini untuk menggambarkan bagaimana konsep bapak sulaiman dalam memberdayakan penyandang disabilitas, dan bagaimana pelaksanaan dalam memberdayakan penyandang disabilitas tersebut.

\section{METODE}

Penelitian ini menggunakan metode penelitian kualitatif, sebuah pendekatan yang menempatkan pandangan peneliti terhadap sesuatu yang di amati secara subyektif. peneliti mendapatkan data melalui wawancara, observasi, dokumentasi. Pemeriksaan keabsahan data dalam penelitian ini menggunakan triangulasi teknik analisis data dilakukan dengan cara reduksi data, penyajian data, dan penarikan kesimpulan. Penelitian kualitatif adalah penelitian yang menggunakan latar alamiah, dengan maksud menafsirkan fenomena yang terjadi dan dilakukan dengan jalan melibatkan berbagai metode yang ada. Dalam penelitian kualitatif, metode yang biasanya dimanfaatkan adalah wawancara, pengamatan, dan pemanfaatan dokumen (Denzin \& Lincoln, 1987). Wawancara dilakukan pada Bapak Sulaiman sebagai pembentuk usaha kecil menengah dengan 10 karyawan yang semuanya mengalami keterbatasan fisik. Hal itu yang membuat peneliti ingin melakukan penelitian secara lebih mendalam mengenai konsep dan pemberdayaan penyandang disabilitas yang dilakukan secara pribadi oleh bapak Sulaiman yang juga mengalami keterbatasan fisik. Penelitian ini letaknya di Jl. Kaliurang No.Km. 13,5, Besi, Sukoharjo, Kec. Ngaglik, Kabupaten Sleman, 
Daerah Istimewa Yogyakarta sebagai pusat pembuatan dan penjualan hasil kerajinan tangan yang sudah di buat oleh penyandang disabilitas.

\section{HASIL}

A. Pengertian Pemberdayaan

Secara etimologis pemberdayaan berasal pada kata dasar "daya" yang berarti kekuatan atau kemampuan. Bertolak dari pengertian tersebut, maka pemberdayaan dapat dimaknai sebagai suatu proses menuju berdaya, atau proses untuk memperoleh daya/kekuatan/kemampuan, atau proses pemberian daya/kekuatan/kemampuan dari pihak yang memiliki daya kepada pihak yang kurang atau belum berdaya (Ambar, 2004).

Proses pemberdayaan masyarakat tersebut terutama dilakukan melalui peningkatan kualitas sumber daya manusia, pengembangan permodalan, pengembangan peluang kerja dan berusaha. Menggerakan sumberdaya untuk mengembangkan potensi yang di miliki masyarakat akan mampu meningkatkan produktivitas sehingga SDA maupun SDM yang ada disekitar masyarakat dapat ditingkatkan produktivitasnya. Strategi pemberdayaan berarti berupaya memberdayakan masyarakat dalam meningkatkan kemampuan yang dimiliki dan mengembangkan potensi, dengan kata lain memberikan keterampilan dan pengetahuan tetapi tidak memberikan dana yang dapat membuat masyarakat tidak dapat untuk mandiri atau tergantung kepada pemerintah (Sunyoto Usman, 2008).

Istilah keberdayaan dalam konteks masyarakat adalah kemampuan individu yang bersenyawa dengan individu-individu yang lainnya dalam masyarakat untuk membangun keberdayaan masyarakat yang bersangkutan. Oleh sebab itu maka pemberdayaan masyarakat adalah upaya memperkuat unsur-unsur keberdayaan itu untuk meningkatkan harkat dan martabat lapisan masyarakat yang berada dalam kondisi tidak mampu dengan mengandalkan kekuatannya sendiri sehingga dapat keluar dari perangkap kemiskinan dan kelatarbelakangan, atau proses memampukan dan memandirikan masyarakat (Kartasasmita, 2007).

\section{B. Konsep Pemberdayaan Mayarakat}

Konsep pemberdayaan masyarakat pada dasarnya adalah upaya menjadikan suasana kemanusiaan yang adil dan beradab yang semakin efektif secara struktural dalam bidang politik, sosial, budaya dan ekonomi baik di dalam kehidupan keluarga, masyarakat, dan negara (Iin Sarinah, dkk, 2019). Serta mempersiapkan masyarakat seiring dengan langkah 
memperkuat kelembagaan masyarakat, agar mereka mampu mewujudkan kemampuan, kemandirian, dan kesejahteraan dalam suasana bersosial selanjutnya (Sumaryadi, 2005).

\section{Penyandang disabilitas}

Seiring dengan Indonesia meratifikasi Konvensi PBB tentang hak-hak penyandang disabilitas (UNCRPD) yang kemudian di tuangkan menjadi Undang-Undang No. 19 tahun 2011, diperkenalkan istilah penyandang disabilitas semiloka terminologi "Penyandang Cacat" dalam rangka mendorong ratifikasi Konvensi Internasional tentang hak-hak penyandang cacat telah diadakan pada 8-9 januari 2009, dihadiri oleh pakar (linguistik, sosial budaya, hukum, hak asasi manusia/ HAM, psikolog).

Dari aspek bahasa kata cacat secara denotatif mempunyai arti yang bernuansa negatif, seperti penderita, kekurangan yang menyebabkan nilai atau mutunya kurang baik, cela, aib, dan rusak. Secara filisofis tidak ada orang yang cacat, manusia di ciptakan tuhan dalam keadaan yang paling sempurna dan dengan derajat yang setinggi-tingginya. Oleh karena itu pemerhati penyandang cacat, LSM, dan masyarakat umum telah menghasilkan kesepahaman tentang pentingnya mengganti istilah penyandang cacat menjadi penyandang disabilitas (Dini Widinarsih, 2019)

UU Nomor 8 tahun 2016 pasal 1 ayat 1 mendefinisikan penyandang disabilitas sebagai orang yang mengalami keterbatasan fisik, intelektual, mental, dan/atau sensorik dalam jangka waktu yang lama yang dalam berinteraksi dengan lingkungan dapat mengalami hambatan dan kesulitan untuk berpartisipasi secara penuh dan efektif dengan warga negara lainnya berdasarkan kesamaan hak. Nama Perusahaan: Fanri Collection yang di dirikan oleh Bapak Sulaiman, bentuk usaha merupakan usaha perorangann yang menghasilkan produk seperti tas, dompet, ikat pinggang, souvenir, gantungan kunci, Dan lain-lain. Letaknya di Jl. Kaliurang No. Km. 13,5, Besi, Sukoharjo, Kec. Ngaglik, Kabupaten Sleman, Daerah Istimewa Yogyakarta. Ia memiliki 10 karyawan dengan daerah pemasaran di Yogyakarta, Jakarta, Malang, Kalimantan, Bandung, Surabaya, Semarang. Visi perusahaan tersebut ialah menjadikan home industri yang menghasilkan produk yang berkualitas yang dapat bersaing di pasar internasional serta memberdayakan penyandang disabilitas sebagai karyawannya. Misi perusahaan ialah menciptakan produk dari bahan kulit ikan pari dan kulit sapi yang berkualitas tinggi, memerdayakan penyandang disabilitas sebagai tenaga kerja, menciptakan kepercayaan konsumen terhadap produk Fanri Collection. 


\section{PEMBAHASAN}

Berdasarkan hasil penelitian, latar belakang berdirinya UKM kerajinan tangan pembuatan dompet, tas, ikat pinggang dll, tidak terlepas dari perjuangan bapak sulaiman pada tahun 1996. Usaha kecil menengah ini pada awalnya adalah usaha milik pribadi yang berbentuk kerajinan tangan dari kulit ikan pari dan kulit sapi. Dari mulai di kerjakannya secara sendiri, alat pengrajin yang terbatas, kurangnya masyarakat yang mengetahui bisnis yang dibangun. Tentu hal itu membutuhkan proses panjang sampai akhirnya saat ini beliau mempunyai staf sekitar 15 penyandang disabilitas karena banyaknya pesanan yang harus di selesaikan.

Tentu dalam meningkatkan kinerja ukm tersebut, beliau tidak segan-segan mengambil resiko untuk menggunakan jasa bank dalam menanggulangi pengeluaran awal dengan jumlah yang cukup besar. Ia mengaku sudah merasakan jatuh bangun, pahit manis dalam membangun bisnisnya tersebut. Ia juga mengaku megalami krisis ekonomi selama 5 tahun pertama di awal membuka bisnis. Hal itu dikarenakan omset yang tidak tetap di setiap bulan. Hal itu disebabkan oleh keterbatasan alat-alat pengrajin, kurangnya staf yang membantu serta kurangnya menejemen pengeluaran dalam bisnisnya. Akhirnya, ia juga berurusan dengan pihak bank karena seringnya menunggak pinjaman yang harus di bayar di setiap bulan.

Dalam pengerjaan bisnis ini bapak sulaiman juga sudah membagi sesuai dengan kemampuan karyawannya. Karena beliau sangat menyadari keterbatasan kliennya. Bapak sulaiman mengaku bahwa ia tidak peduli dengan latar belakang hidup dan latar belakang pendidikan karyawannya karena ia memahami bagaimana sulitnya mencari sekolah untuk orang-orang difable di masanya dulu.

Menurut pengalamannya waktu masih sekolah di Sekolah Dasar di Jakarta, ia pernah pindah sekolah karena teman sebayanya mengejek bapak sulaiman yang mengalami cacat fisik yaitu hanya memiliki satu kaki, sampai akhirnya ia memutuskan berhenti sekolah dan mencari pekerjaan ketika sudah menginjak remaja. Akan tetapi bapak sulaiman juga mengalami kesulitan karena tidak mempunyai latar belakang pendidikan yang baik serta kurangnya lapangan pekerjaan yang ramah dengan orang-orang penyandang disabilitas.

Setelah mendapatkan pelayanan dari pusat rehabilitasi, bapak sulaiman merasa bisa melakukan pekerjaan yang berhubungan dengan tangan, seperti menjahit, melukis dan mengukir. Karena dukungan keluarga dan juga istrinya waktu itu, bapak sulaiman mulai 
merintis usaha kecil yaitu membuat dompet. Sampai akhirnya ia mulai mengasah keahliannya dan menerima berbagai pesanan serta memiliki karyawan.

A. Konsep Pemberdayaan Penyandang Disabilitas yang dilakukan oleh bapak Sulaiman

Pekerjaan adalah sebuah aktivitas yang menjadi rutinitas bagi semua orang, pekerjaan tertentu dapat meningkatkan status sosial seseorang agar tetap exis di kehidupannya. Selain itu pekerjaan juga menjadi hal yang dibutuhkan oleh manusia karena dapat menunjang kebutuhannya setiap hari. kebutuhan yang semakin banyak akan memicu sesorang untuk bekerja lebih keras dan lebih giat lagi, karena mencari nafkah itu adalah hal yang wajib dilakukan apalagi oleh kepala rumah tangga. Kewajiban bekerja juga dijelaskan oleh

Undang-undang Nomor 8 pasal 11 tahun 2016 tentang penyandang disabilitas sudah mengatur ketentuan dan hak difabel dalam bekerja, wirausaha dan koperasi. Penyandang disabilitas juga mempunyai hak memperoleh pekerjaan yang di selenggarakan oleh pemerintah, pemerintah daerah atau pemerintah swasta tanpa deskriminasi. Undang-undang Pasal 3 tahun 2016 juga menegaskan bahwa pemerintah daerah, badan usaha milik negara, dan badan usaha milik daerah wajib mempekerjakan paling sedikit $2 \%$ (dua persen) penyandang disabilitas dari jumlah pegawai atau pekerja.

Hal itu sudah jelas bahwa tidak ada pengecualian dalam bekerja dan membentuk usaha bagi masyarakat yang mengalami keterbatasan fisik. Oleh karena itu bapak sulaiman yang mendirikan UKM kerajinan tangan ini belum pernah gulung tikar selama hampir 25 tahun berjalan usahanya. Selain mendapatkan dukungan materi dari kerabat dekat, ia juga mendapatkan dukungan secara penuh dari keluarganya. Tentu hal itu membuat bapak sulaiman menjadi sangat menggeluti dan ulet dalam menjalankan bisnisnya.

Usaha Kecil Menengah yang terletak di jalan kaliurang ini sudah cukup populer di kalangan masyarakat maupun wisatawan, karena ia menerima berbagai jenis pesanan dari mulai dompet, tas, ikat pinggang dll, harga yang di bandrol juga sangat fantastik karena hampir mencapai harga 3 juta untuk satu tas wanita yang terbuat dari kulit ikan pari, tentu hal itu juga diperhatikan panjang lebar design tasnya dan aksesoris yang terpakai.

Selain tas, bapak sulaiman dan rekannya juga menerima berbagai pesanan dompet dari berbagai brand yang nantinya akan di pasarkan di salah satu Mall di Yogyakarta. Bahkan beberapa brand yang bersaing di Yogyakarta juga melakukan pemesanan di 
tempat yang sama yaitu di tempat usaha milik bapak sulaiman, akan tetapi beliau menuturkan bahwa tidak pernah membeda-bedakan harga atau pun kualitas bahan terhadap brand yang memesan, karena ia menyadari bahwa tugas pengrajin hanyalah membuat dompet atau tas sesuai dengan design yang sudah di berikan oleh brand tersebut.

Bapak sulaiman juga menjelaskan proses pengolahan kulit ikan pari yang di mulai dengan memisahkan kulit dari daging, setelah itu kulit harus di awetkan dengan penggaraman. Proses penggaraman tersebut pun membutuhkan waktu yang sangat lama. Dalam proses penggaraman kulit ikan pari mengalami proses penyamakan. Setelah semua proses penggaraman selesai, kulit setengah jadi bisa di warnai dengan zat warna khusus yang dapat menyerap pada sisik padatnya. Proses berikutnya adalah pembuatan barang menjadi kerajinan, dalam tahap kerajinan yang paling sulit ketika tahap menjahit karena sisik ikan pari yang sangat keras dan padat.

UKM "Fanri Collection" membentuk kulit ikan pari sesuai dengan pesanan pelanggan. Seluruh proses pengolahan kulit ikan pari dari pengulitan hingga di hasilkan barang jadi memerlukan waktu setengah bulan atau sesuai dengan banyaknya pesanan yang di minta oleh pelanggan. Rumitnya teknologi pengolahan kulit ikan pari membuat skala pengrajin tidak bisa menjadi masal seperti penganyaman kulit sapi atau ular, namun potensi pasarnya masih sangat besar bahkan bapak sulaiman sudah mengekspor hasil kerajinannya ke pasar Asia, dan Amerika.

Bapak Sulaiman juga menyediakan pemesanan per produk, supplier kulit berasal dari berbagai macam daerah seperti suplier kulit biawak dari daerah Yogyakarta dan sekitarnya. Supplier kulit ikan pari dari serang banten sedangkan kulit sapi dari Magetan Jawa Timur. Pengiriman menggunakan ekspedisi seperti JNT, JNE, Pos dll. Untuk menjaga kenyamanan pelanggan, pengiriman di lakukan sesuai dengan waktu yang sudah di tetapkan oleh konsumen.

Proses pengerjaan tas, dompet, aksesoris dan lain-lainnya bapak sulaiman membagi staffnya sesuai dengan kemampuan masing-masing. Mulai dari menghaluskan bahan, membersihkan, menandai ukuran dompet sesuai pesanan konsumen, menggunting, menjahit, serta mengoles cairan pada dompet agar dompet yang sudah jadi lebih menarik untuk di pasarkan. 
Hasil penelitian lapangan menunjukkan bahwa usaha kecil menengah milik bapak sulaiman mempunyai konsistensi yang stabil dalam pembuatannya. Hal itu dapat di buktikan dengan semakin bertambahnya jumlah pemesanan dan semakin luas jangkauan yang sudah diraihnya. Bapak sulaiman juga mengaku bahwa ia bisa mendapatkan omset sekitar kurang lebih dari 50 juta di setiap bulannya. hal itu ia dapatkan sebelum pandemi. Bahkan setelah pandemi bapak sulaiman dan karyawannya masih dapat menghasilkan omset kurang lebih dari 25 juta di setiap bulannya.

Setiap pemesanan yang ia terima juga tidak luput dari kesepakatan bersama rekan kerjanya. Ia mengaku selalu melibatkan karyawannya untuk menentukan apakah akan menerima pesanan, berapa lusin dompet dan tas yang bisa dikerjakan dan apakah karyawannya dapat melakukannya. Tentu hal ini adalah sikap yang jarang sekali dimiliki oleh pemilik usaha, ia benar-benar menganggap karyawannya seperti keluarga sendiri dan melihatnya tanpa perbedaan apapun.

Dengan sikap bijaksana serta kebaikan bapak sulaiman membimbing dan menemani karyawannya dalam bekerja, ia dapat menghasilkan bibit-bibit unggul di kampungnya. Hal itu dapat di buktikan dengan penelitian lapangan bahwa ia sudah dapat mempekerjakan 5 karyawannya secara mandiri. Kelima karyawan tersebut sempat bekerja bersama dengan bapak sulaiman hampir belasan tahun sampai akhirnya ia mendapatkan kesempatan membangun usahanya sendiri dirumahnya.

Usaha yang dibangun pun sama dengan bapak sulaiman, akan tetapi bapak sulaiman mengaku tidak pernah merasa keberatan dengan hal itu, ia yakin semua orang berhak mendapatkan kesempatan yang sama tergantung bagaimana usaha yang di lakukan oleh setiap individunya. Ia tidak merasa tersaingi karena ia menyadari keterbatasan dirinya dan karyawannya dalam mengerjakannya. Berikut penuturan yang disampaikan oleh bapak sulaiman dalam wawancara yang di lakukan oleh peneliti "saya dan temanteman disini terkadang menolak beberapa pesanan mbak karena merasa tidak bisa menyelesaikan sesuai dengan waktu yang di tentukan oleh pelanggan, mengingat banyaknya pesanan yang juga masih dikerjakan, dan biasanya saya sarankan mereka untuk datang ke tempat karyawan saya yang sudah melakukan usaha mandiri dirumahnya".

Tujuan bapak sulaiman memberikan peluang pekerjaan pada penyandang disabilitas karena sulitnya lapangan pekerjaan yang bisa di dapatkan oleh orang-orang 
difabel. Hal itu juga sempat di alami oleh bapak sulaiman sewaktu masih muda dalam mencari lapangan pekerjaan. Bapak sulaiman tersebut juga merupakan penyandang disabilitas yang mahir dalam membuat kerajinan tangan. Keterbatasan fisik ternyata tidak menyusutkan semangatnya dalam berwirausaha. Meskipun diterpa badai puluhan kali ia tetap berdiri dengan keyakinannya sendiri bahwa dirinya bisa melakukan usaha dan berkembang seperti masyarakat pada umumnya.

Selain dikenal sebagai pemilik usaha kecil menengah kerajinan tangan bapak sulaiman juga dikenal sebagai orang yang menginspirasi. Banyak mahasiswa dan pemerintah daerah melakukan penelitian dan kunjungan ketempat tersebut guna mengetahui lebih dalam bagaimana proses pembuatan serta perjalanan bapak sulaiman hingga mendapatkan omset ratusan juta.

B. Manfaat Pemberdayaan Penyandang Disabilitas

Seperti yang sudah di paparkan di atas, pemberdayaan dilakukan untuk membantu masyarakat agar dapat melakukan aktivitas baik itu pekerjaan ataupun dalam melakukan aktivitas sehari-hari. Hal itu dapat kita lihat dari kehidupan para difable yang menjadi karyawan di UKM milik bapak Sulaiman. Beberapa difable memutuskan menikah setelah bekerja sudah cukup lama dengan bapak sulaiman. Mereka mengaku bahwa, pekerjaannya membantu mereka dalam menafkahi istri, anak dan keluarga mereka.

Meskipun telah menikah beberapa karyawan disana memutuskan untuk merantau dan bekerja di Yogyakarta. Selain sudah terbiasa di jogja, mereka mengaku juga sudah nyaman bekerja dengan bapak sulaiman dan sudah di anggap sebagai keluarga sendiri. Bapak sulaiman juga memberikan waktu libur untuk mereka agar mereka bisa pulang ke kampung halaman masing-masing, jika ada kepentingan mendesak bapak sulaiman juga mengizinkan untuk pulang meskipun masih belum waktunya libur.

Sesuai dengan tujuan di adakannya pemberdayaan oleh bapak sulaiman, maka bapak sulaiman sebagai pemilik bisnis pun tidak mengekang atau membuat peraturan yang sangat ketat terhadap karyawannya dalam bekerja. Selain itu bapak sulaiman juga ikut serta dalam bekerja. Hal itu yang membuat karyawannya nyaman dan betah berada disana. Selama satu minggu peneliti ikut berbaur dengan mereka, bapak sulaiman sebagai pemilik usaha benar-benar memperlakukan karyawannya selayaknya keluarga. Menggunakan bahasa yang santun, dan tidak bersikap seenaknya kepada karyawannya. Hal itu dapat dilihat dari cara ia memberikan waktu luang untuk istirahat, sholat dan 
makan siang. Suasana di tempat kerja mereka sangat nyaman karena tidak ada ketercanggungan antara atasan dan bawahan. Meskipun begitu, karayawan bapak sulaiman juga sangat menghormati bapak sulaiman sebagai pemilik usaha pengrajin di tempat tersebut. Mereka mengaku bahwa bapak sulaiman sangat baik dan selalu memberikan gaji karyawannya sesuai tanggal penerimaan.

Di lihat dari tujuan pemberdayaan, bapak sulaiman berhasil dalam mewujudkan UKM sebagai tempat memberdayakan para teman-teman yang difable. Meskipun UKM "Fanri Collection" yang di bangun oleh bapak sulaiman bukanlah sebuah lembaga, akan tetapi manfaatnya tidak berkurang sedikit pun untuk teman-teman difable. Bapak sulaiman masih terus mengusahakan yang terbaik untuk para karyawannya agar mereka tetap bekerja dan tetap mempunyai penghasilan, ia mengaku sangat ingin bermanfaat bagi teman-teman difable karena sangat sulitnya lapangan pekerjaan bagi bagi dirinya dan teman-teman difable.

\section{SIMPULAN}

Dari hasil observasi dan wawancara, pusat rehabilitasi memberikan pelayanan bagi masyarakat disabilitas agar bisa mempunyai keterampilan yang nantinya akan di gunakan untuk memasuki dunia kerja. Adanya pelayanan pusat rehabilitasi bagi penyandang disabilitas memudahkan para difabel untuk mendapatkan ruang agar dapat meningkatkan kualitas diri melalui bimbingan dari pusat rehabilitasi. Pemberdayaan masyarakat difabel sangatlah penting agar masyarakat yang menyandang disabilitas bisa mendapatkan pekerjaan sesuai dengan keterampilannya. Seperti Bapak Sulaiman yang merupakan salah satu orang yang mengalami tuna daksa tetapi berhasil memiliki usaha kecil menengah dengan 15 karyawan. 10 karyawan yang masih bersama dengan bapak Sulaiman dan 5 orang karyawan sudah bisa membentuk usaha mandiri dirumah masing-masing.

Setelah melakukan penelitian dan analisa penelitian dapat diketahui bahwa kurangnya lapangan pekerjaan bagi penyandang disabilitas juga menjadi kendala utama kaum difabel dalam menyalurkan keterampilannya. Untuk daerah tingkat dua di seluruh indonesia agar mematuhi peraturan daerah tentang kewajiban mempekerjakan kaum difabel sebanyak $2 \%$ dari jumlah karyawan seperti yang sudah di paparkan di Undang-undang Pasal 3 tahun 2016. 


\section{DAFTAR RUJUKAN}

Aesah, Harsono, and Jaswita, (2020)"Pemberdayaan Difabel Melalui Usaha Ekonomi Produktif (Uep) Di Desa Kediri, Kecamatan Kediri, Kecamatan Kediri, Kecamatan Lombok Barat Nusa Tenggara Barat".

Afifuddin Dan Beni Ahmad. (2009). Metodologi Penelitian Kualitatif. Bandung: Pustaka Setia.

Ambar, Teguh Sulistiyani. (2004). Kemitraan Dan Model-Model Pemberdyaan. Yogyakarta: Gava Media.

Aminah, Suprihatiningrum, and Hanjarwati, "PRODADISA 'Program Pemberdayaan Difabel Daksa' menuju Percontohan BKD (Balai Kerja Difabel) untuk Meningkatkan Kemandirian dan Life Skill Difabel.” Inklusi, Vol. 2 No. 2 Juli 2015

Aprianto, (2019) "Pengaruh Pengalaman Kerja Dan Pengembangan Karir Terhadap Kinerja Karyawan Pada Pt Sinar Niaga Sejahtera Kota Lubuk Linggau”.

Dini Widinarsih, (2019) "Penyandang Disabilitas di Indonesia: Perkembangan Istilah dan Definisi”.

Hamidi (2008). Metode Penelitian Kualitatif. Malang: UMM Press.

Hardani, Dkk, (2020) Metode Penelitian Kualitatif Dan Kuantitatif, Yogyakarta: CV. Pustaka Ilmu Group

Hendra Wijayanto. Empowerment Disabilities in the Implementation of the Program Joint Business Group (Kube) in the Village Suruh Tasikmadu District, District Karanganyar. The Indonesian Journal of Public Administration. Vol. 1 No. 2, Juli 2015

Mahmud. (2011). Metode Penelitian Pendidikan. Bandung: CV Pustaka Setia.

Mulyati, Utami, and Susilo, "Pemberdayaan Siswa Berkebutuhan Khusus Melalui Keterampilan Untuk Melatih Kemandirian Di Slb Psm Takeran - Magetan.” Jurnal Terapan Abdimas, Vol. 6 No. 1 Januari 2021

Patilima, Hamid. (2007) Metode Penelitian Kualitatif. Jakarta: Alfabeta

Puspawati, Praswati, and Wahyuddin, "Analisis Program Pemberdayaan Difabel Menuju Kemandirian Ekonomi." Seminar Nasional dan The 6th Call for Syariah Paper Universitas Muhammadiyah Surakarta.

Sarinah, Sihabudin, And Suwarlan, (2019) "Pemberdayaan Masyarakat Dalam Bidang Ekonomi Oleh Pemerintah Desa Pangandaran Kecamatan Pangandaran Kabupaten Pangandaran".

Sumaryadi. (2005) Perencanaan Pembangunan Daerah Otonom dan Pemberdayaan Masyarakat. Jakarta: CV Citra Utama

Triyanto et al., "PEMBERDAYAAN KOMUNTAS DIFABEL MELALUI PRODUKSI VARIASI MAKANAN KECIL." Jurnal Ilmiah Pengabdian Kepada Masyarakat Pakem, Vol. 1 No. 1 September 2019. 